\title{
PETTY OFFENDERS HAVE NO PEERS!
}

\author{
George Kaye $\dagger$
}

HE UNITED STATES CoNSTITUTION provides in Article III that "[ $t$ ]he trial of all crimes, except in cases of impeachment, shall be by jury;" and the Sixth Amendment prescribes that "[i]n all criminal prosecutions the
accused shall enjoy the right to a speedy and public trial, by an impartial jury. ..."2 (Italics added.) Comprehensive though these provisions may seem on their face, ${ }^{3}$ they do not, according to authors Felix Frankfurter and Thomas G. Corcoran, apply to prosecutions of certain federal crimes denominated "petty offenses." Consequently, persons accused of such crimes are denied trial by jury in the federal courts. ${ }^{6}$

The present writer believes that this result reflects an undesirable technique

$\dagger$ Member of the Chicago bar.

1 "The Trial of all Crimes except in Cases of Impeachment, shall be by Jury; and such Trial shall be held in the State where the said Crimes shall have been committed; but when not committed within any State, the Trial shall be at such Place or Places as the Congress may by Law have directed." U.S. Const. Art. III, §2, para. 3.

2 "In all criminal prosecutions, the accused shall enjoy the right to a speedy and public trial, by an impartial jury of the State and district wherein the crime shall have been committed, which district shall have been previously ascertained by law, and to be informed of the nature and cause of the accusation; to be confronted with the witnesses against him; to have compulsory process for obtaining witnesses in his favor, and to have the assistance of counsel for his defence." U.S. Const. Amend. VI.

${ }^{3}$ Ex parte Milligan, 4 Wall (U.S.) 2, 123 (1866): "[I]f ideas can be expressed in words, and language has any meaning, this right [of jury trial]-one of the most valuable in a free country -is preserved to every one accused of crime who is not attached to the army or navy or militia in actual service. The sixth amendment affirms that in all criminal prosecutions the accused shall enjoy the right to a speedy and public trial by an impartial jury,' language broad enough to embrace all persons and cases. ..." (Italics added.) Accord: Federal Rules of Criminal Procedure with Notes and Institute Proceedings 172 (1946).

${ }^{4}$ Frankfurter and Corcoran, Petty Federal Offenses and the Constitutional Guaranty of Trial by Jury, 39 Harv. L. Rev. 917 (1926). [Hereafter referred to simply as Frankfurter and Corcoran.]

5 The problem of defining "petty offenses" is discussed in the text at note 165 infra. Congress has formulated this statutory definition: "Notwithstanding any Act of Congress to the contrary: (1) Any offense punishable by death or imprisonment for a term exceeding one year is a felony. (2) Any other offense is a misdemeanor. (3) Any misdemeanor, the penalty for which does not exceed imprisonment for a period of six months or a fine of not more than $\$ 500$, or both, is a petty offense." 62 Stat. 684 (1948), 18 U.S.C.A. \$1 (1950).

6 District of Columbia v. Clawans, 300 U.S. 617 (1937); Bailey v. United States, 98 F.2d 306 (App.D.C., 1938); Perlich v. District of Columbia, 90 A.2d 227 (Mun.Ct.App.D.C., 1952); Savage v. District of Columbia, 54 A.2d 562 (Mun.Ct.App.D.C., 1947); Rogers v. District of Columbia, 31 A.2d 649 (Mun.Ct.App.D.C., 1943); Smith v. United States, 128 F.2d 990 (C.A.5th, 1942) (semble); Latiolais v. United States, 129 F.2d 323 (C.A.5th, 1942) (semble); United States v. Au Young, 142 F.Supp. 666 (D.C. Hawaii, 1956) (semble); United States v. Great Eastern Lines, 89 F.Supp. 839 (E.D.Va., 1950) (semble); see Green v. United States, 356 U.S. 165, 201 n.11 (1958). 
of Constitutional interpretation and amounts to an unwarranged abrogation by the federal government of a Constitutional right. Accordingly, it is his purpose in this article to examine the argument which purports to require such result and to demonstrate that in history and in logic it fails to do so. His ultimate object is to re-establish the rule which prevailed under the Constitution for one hundred and forty-seven years: mandatory jury trial on demand by the defendant in all criminal cases currently disposed of summarily from the federal bench. ${ }^{7}$

\section{Sunmary Trials in England and in the Colonies}

The keystone of the position taken by Frankfurter and Corcoran is that the words "crimes" and "criminal" as used in the Constitution refer solely to major transgressions of the penal law and do not encompass the minor crimes known as "petty offenses." They argue that the extensive prosecution of these crimes without the intervention of a jury in England, ${ }^{9}$ the colonies,,$^{10}$ and the newly constituted states, ${ }^{11}$ and the absence of debate on this subject in the Federal Convention and the First Congress, ${ }^{12}$ suggest no intent on the part of the drafters to abolish the prior summary practice and that therefore the Constitution requires no alteration of that practice.

Existence of summary trials in England and the colonies is indisputable..$^{13}$ However, it is not a necessary implication of this summary practice that our Constitutional language fails to embrace the less serious offenses. For the English and colonial practice was fostered, not by a Constitutional guarantee that "[t]he trial of all crimes ... shall be by jury ...,"14 but by the provision of Magna Carta declaring that "no freeman shall be taken, or imprisoned, or exiled, or in any other manner destroyed, except by the judgment of his peers, or by the law of the land."15 (Italics added.)

Magna Carta's judicium parium was, albeit erroneously, ${ }^{16}$ identified by

7 The most recent application of the rule occurred in Blackburn v. United States, 84 F.2d 269 (App.D.C., 1936). According to Owings v. Speed, 5 Wheat. (U.S.) 420 (1820), the Constitution became operative in March, 1789.

${ }^{8}$ Frankfurter and Corcoran 969-75.

${ }^{9} \mathrm{Id}$., at $\mathbf{9 2 5 - 2 6 .}$

${ }^{10} \mathrm{Id}$., at 936.

11 Id., at $937,968$.

12 Id., at $968-70$.

${ }_{13}$ Williams v. Augusta, $4 \mathrm{Ga} .509$ (1848); State v. Glenn, 54 Md. 572 (1880); Wilmarth v. King, 74 N.H. 512, 69 Atl. 889 (1908); State v. Griffin, 66 N.H. 326, 29 Atl. 414 (1890); Katz v. Eldredge, 97 N.J.L. 123, 117 Atl. 841 (1922); McGear v. Woodruff, 33 N.J.L. 213, 216 (1868); Johnson v. Barclay, 1 Harrison (N.J.) 1, 6 (1837); Commissioners of New Town Cut v. Seabrook, 2 Strob. L. (S.C.) 560 (1846); Trigally v. Memphis, 6 Cold. (Tenn.) 382, 385 (1869); Ex parte Marx, 86 Va. 40, 48, 9 S.E. 475, 478 (1889); 4 Blackstone Comm. 277 (1st Am. ed., 1772).

14 See note 1 supra.

${ }^{15}$ The writer's rendition of the Latin of Magna Carta quoted in 4 Blackstone Comm. 343. Compare the numerous state constitutional provisions cited in note 119 infra.

${ }^{16}$ Frankfurter and Corcoran 923 n.16. 
Blackstone with the traditional common-law jury. ${ }^{17}$ As to this identification, there is no indication that either the framers of the American state and national constitutions or their colonial ancestors differed with him. Consequently, to Blackstone's American students it would have been only natural to regard the right to a criminal jury as a protection generally in existence under Magna Carta except where the positive law of Parliament or the colonial legislatures made explicit inroads upon it.

So understood, the controlling law did not purport to assure a jury in all criminal prosecutions, or in any particular class of them. It merely established that the citizen's liberty was secured by two disjunctively expressed safeguards against imposition on the part of the government. He was entitled to protection either "by the judgment of his peers," "18 with its requirement of unanimous condemnation from twelve laymen like himself, or "by the law of the land," 19 on the stability and generality of which he had theretofore been content to rely.

Although Parliament was plainly empowered by Magna Carta to dispense with the criminal jury in the prosecution of any offense as to which summary trial was made the law of the land, and although it used this power extensively, the fact remains that the summary practice which resulted did not occur as an exception to a provision purporting to regulate "crimes" generally. Therefore, it cannot be inferred that the English and colonial practice precludes any but a restricted meaning of the word "crimes" as used in Article III. On the contrary, what happened in England and the colonies is clearly consistent with a fully comprehensive signification of this term, because it was absent from the relevant provision of Magna Carta.

There is an additional reason for rejecting the English practice as authority for the exclusion of "petty offenses" from our Constitutional jury guarantees. If that practice proves anything at all in this connection, it proves too much. For as Frankfurter and Corcoran point out, ${ }^{20}$ summary trials in England were not restricted to such crimes. Prosecutions of serious derelictions were also authorized without jury intervention. ${ }^{21}$ Indeed, Blackstone was moved by the constantly increasing scope of the summary jurisdiction to lament that it "has of late been so far extended, as, if a check be not timely given, to threaten the disuse of our admirable and truly English trial by jury, unless only in capital cases"! !22 (Italics added.)

But Frankfurter and Corcoran do not carry their argument to the full extent of the English practice. Had they done so they would have infringed upon the

173 Blackstone Comm. 350; 4 id., at 342.

${ }^{18}$ See text at note 15 supra.

${ }^{19}$ Ibid.

20 Frankfurter and Corcoran 927.

${ }^{21}$ E.g., 22 \& 23 Car. II, c.7 (1670), punished, apparently without jury trial, the burning of houses at night with transportation for seven years, and made the offense a felony. Consult Frankfurter and Corcoran 927 n.34; id., at 960 n.216; Md. Sess. Laws, c.3 (1782).

224 Blackstone Comm. 277-78. 
decision in Callan $v$. Wilson, ${ }^{23}$ a Supreme Court case on which they rely in another connection. ${ }^{24}$ That case holds a misdemeanor prosecution to be within the Constitutional jury trial requirements, and thus denies to Congress the full range of the dispensing power exercisable and exercised by Parliament. ${ }^{25}$ So the English practice proves to be an unsatisfactory authority in two respects: it is equivocal in supporting either a broad or a narrow reading of "crimes" in Article III; and insofar as it suggests a narrow meaning it indicates one even more restricted than the interpretation of Frankfurter and Corcoran. ${ }^{26}$ It is therefore necessary to look elsewhere for authority to omit "petty offense" prosecutions from our Constitutional criminal jury guarantees.

\section{Stumarary Trials onder the Eardy State Constitutions}

Frankfurter and Corcoran limit their discussion of the colonial practice to Massachusetts, ${ }^{27}$ Connecticut, ${ }^{28}$ New York, ${ }^{29}$ New Jersey, ${ }^{30}$ Pennsylvania, ${ }^{31}$ Maryland ${ }^{32}$ and Virginia..$^{33}$ Their treatment of the early state summary practice is confined to incidental recognition ${ }^{34}$ and rather broad assertion. ${ }^{35}$ Since the present writer merely challenges the validity of their conclusion, he will assume that summary trials took place in all thirteen original states. Nevertheless, such practice gives only equivocal support to the Frankfurter-Corcoran thesis, since the state practice too is equally consistent with the broadest interpretation of our Constitutional jury assurances.

A. Connecticut, Rhode Island, South Carolina.-Not all of the thirteen states adopted constitutions before the Philadelphia Convention in 1787. Connecti-

${ }^{23} 127$ U.S. 540 (1888).

24 Frankfurter and Corcoran 977.

${ }^{25}$ See note 21 supra.

${ }^{26}$ Blackstone observed that vulgar usage sometimes equated "crimes" and "felonies" by opposing "crimes" to "misdemeanors," thus giving rise to a limited meaning of "crimes" even though, properly speaking, the word was synonymous with "misdemeanors." 4 Blackstone Comm. 5. This vulgar usage, if it proved anything would also prove too much, for it would engulf all misdemeanors in the category of summarily triable "petty offenses." However, District of Columbia v. Colts, 282 U.S. 63 (1930), and Callan v. Wilson, 127 U.S. 540 (1888), prevent that engulfment by requiring jury trial of indictable misdemeanors. Furthermore, the occasional restriction in meaning noted by Blackstone is far from conclusive when that author himself regularly employs the word "crimes" in its broad sense. E.g., 4 Blackstone Comm. 1-2.

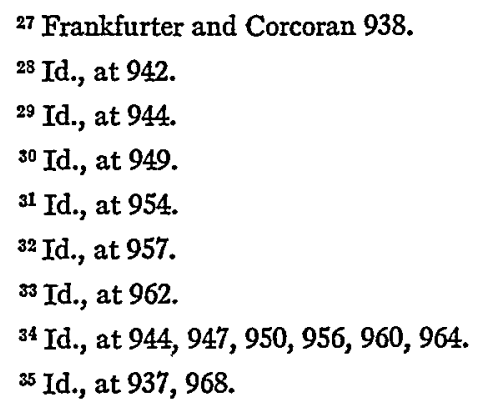


cut's first written constitution is dated $1818 .^{36}$ Prior thereto, the state was governed according to English law under its colonial charter. ${ }^{37}$ As we have seen, that law did not purport to regulate "crimes" generally and explicitly provided for legislative abrogation of the criminal jury. Consequently, the same considerations adduced in the preceding discussion of the English and colonial summary practice apply to and dispose of such practice in the state of Connecticut.

The Connecticut case of Goddard v. State, ${ }^{38}$ relied upon by Frankfurter and Corcoran, ${ }^{39}$ does not affect such disposition in the least. That case was decided in 1838 under the constitutional provision of 1818 assuring a criminal jury in prosecutions by indictment or information only. ${ }^{40}$ Since the defendant had been charged with violating the Sabbath, not by indictment or information but $b y$ complaint, of course he was properly denied a jury trial. The case clearly failed to come within the terms of the patently restricted jury assurance under which it arose. Furthermore, the decision came half a century after the Philadelphia Convention, and thus it certainly does not establish the existence of a narrow sense of the Constitutional language in the understanding of the Convention delegates.

Rhode Island had no written constitution until $1842 . .^{41}$ Like Connecticut, it governed itself under the English law incorporated by its colonial charter as amended from time to time. ${ }^{42}$ Thus any summary practice in the state is as equivocal for the purposes of Frankfurter and Corcoran as that already discussed.

South Carolina adopted a constitution in $1778,{ }^{43}$ which was still in effect in 1787. It contained no reference to trial by jury as such, but paraphrased ${ }^{44}$ the assurance of Magna Carta. ${ }^{45}$ Here too there was no change in the pre-existing law, so the foregoing disposition of the English and colonial practice applies as fully to South Carolina as to Connecticut and Rhode Island.

B. New Jersey, North Carolina, Georgia, New York.-In 1776 New Jersey adopted a constitution which declared that "the inestimable right of trial by jury shall remain confirmed, as a part of the law of this colony, without repeal

${ }^{36} 1$ Thorpe, American Charters, Constitutions \& Organic Laws 536 (1909). Accord: Frankfurter and Corcoran 944 n. 130.

${ }^{37}$ Beard and Beard, A Basic History of the United States 117 (1944); Coleman, The Constitution and Its Framers 7-8 (1910).

${ }^{38} 12$ Conn. 448 (1838).

${ }^{39}$ Frankfurtér and Corcoran 944.

${ }^{40}$ Conn. Const. Art. I, $\$ 9$ (1818).

${ }^{41} 6$ Thorpe, op. cit. supra note 36 , at 3222 .

12 See note 37 supra.

${ }^{43} 6$ Thorpe, op. cit. supra note 36 , at 3248 .

${ }^{44}$ S.C. Const. $\$ 41$ (1778): ". . . no freeman of this State [shall] be taken or imprisoned, or disseized of his freehold, liberties, or privileges, or outlawed, exiled or in any other manner destroyed or deprived of his life, liberty, or property, but by the judgment of his peers or by the law of the land."

${ }^{45}$ See text at note 15 supra. 
for ever." ${ }^{36}$ (Italics added.) Similar constitutional provisions quickly followed in North Carolina, ${ }^{47}$ Georgia ${ }^{48}$ and New York. ${ }^{49}$ The significance of these provisions is that they preserved the right to a criminal jury against legislative inroad only as that right had been delimited by previous custom.

The previous custom thus explicitly incorporated was the English and colonial practice described above. Taken by itself that practice has proved inadequate to compel the conclusion favored by Frankfurter and Corcoran. Its constitutional adoption in these four states does not make it any less equivocal. There was still no provision purporting to require jury trial of "crimes" generally, out of which the persistence of summary trials might have carved an exception. Furthermore, there is still no certain criterion by which the incorporated practice can be cut down to the "petty offenses" which concern Frankfurter and Corcoran. And we have now reviewed England, the colonies and seven of the original thirteen states.

C. Massachusetts, New Hampshire.-In 1780 Massachusetts constitutionally proscribed legislative attempts to inflict capital punishment on any person without trial by jury.$^{50}$ Four years later New Hampshire did the same. ${ }^{51}$ Summary practice under such a provision lends no more support to the FrankfurterCorcoran thesis than did the practice in all the jurisdictions heretofore considered. Again it is plain that no general assurance of a jury in the trial of all "crimes" is involved, since the Massachusetts type of provision applies to major malefactions only. Moreover, the capital punishment limitation clearly permits abrogation of the criminal jury in cases of crimes more serious than "petty offenses." Accordingly, the objections already noted to this entire line of argument by Frankfurter and Corcoran extend to these two New England states also.

D. Virginia, Delaware, Pennsylvania, Maryland.-The jury guarantees of the remaining four states all date from 1776. Virginia, the first of them, stated in its Declaration of Rights that "in all capital or criminal prosecutions a man hath a right ... to a speedy trial by an impartial jury of 12 men of his vicinage, without whose unanimous consent he cannot be found guilty. . . ." ${ }^{53}$ Absent the

${ }^{46}$ N.J. Const. \$22 (July 3, 1776).

${ }^{47}$ N.C. Const. $\S 9$ (December 18, 1776): "“. . no freeman shall be convicted of any crime, but by the unanimous verdict of a jury of good and lawful men, in open court as heretofore used;" $\$ 14:$ ". . . trial by jury ... to remain sacred and inviolable." (Italics added.)

${ }^{48} \mathrm{Ga}$. Const. $\$ 61$ (February 5, 1777): "... trial by jury, to remain inviolate forever." (Italics added.)

${ }^{49}$ N.Y. Const. $\$ 41$ (April 20,1777): “. . . trial by jury, in all cases in which it hath heretofore been used in the colony of New-York, shall be established and remain inviolate for ever." (Italics added.)

${ }^{\text {so }}$ Mass. Declaration of Rights Art. XII (1780): "And the legislature shall not make any law, that shall subject any person to a capital or infamous punishment, excepting for the government of the army and navy, without trial by jury."

${ }^{51}$ N.H. Bill of Rights Art. 16 (1784): "Nor shall the legislature make any law that shall subject any person to a capital punishment, excepting for the government of the army and navy, and the militia in actual service, without trial by jury."

${ }^{52}$ Va. Declaration of Rights $\$ 8$ (June 12, 1776). 
words "or criminal," this provision would be identical in substance to those of Massachusetts and New Hampshire already shown to have no significance for the Frankfurter-Corcoran thesis. Since the words are present, we will for the moment assume that the Virginia guarantee is favorable to that thesis; i.e., that in this Declaration of Rights we find the provision purporting to regulate "crimes" and "criminal prosecutions" generally which has become so conspicuous by its absence from all the jurisdictions thus far considered. In Virginia's summary practice we would then encounter our first concrete historical evidence that the vital terms did not comprehend all penal violations.

Even assuming that Virginia's limited use of the criminal jury under its Declaration of Rights may authorize exclusion of some criminal proceedings from the national jury assurances, it remains necessary to examine the Virginia practice to see whether the exception created by it corresponds to the "petty offenses" of the Frankfurter-Corcoran argument. Examination, however, reveals no such correspondence. Instead, it discloses a most puzzling discrepancy.

On May 30, 1778, the Virginia legislature passed a bill of attainder. The bill attainted Josiah Philips and his cohorts as traitors and prescribed a penalty to be imposed upon them unless they surrendered themselves to the state officials within thirty days after its passage. For present purposes the most interesting aspects of this bill are that it imposed a criminal penalty upon the accused persons without benefit of jury trial, and that this penalty consisted not of a mere jail sentence but of death! ${ }^{53}$

Obviously this legislation cannot be harmonized with the jury guarantee in the Virginia Declaration of Rights on the ground that the word "criminal" does not include "petty offenses." The bill authorized infliction of the gravest punishment in retribution for the most serious offense. The only possible explanation of the discrepancy between the jury assurance and the bill is that the Declaration of Rights was only a statute, subject to repeal by subsequent inconsistent legislation.

There is no novelty in this explanation. Its validity was acknowledged by such celebrated Virginians as James Madison and Thomas Jefferson. Instances of such "unconstitutional" legislation were numerous from 1776 to 1787 and thereafter, and these "unconstitutionalities" were contemporaneously justified on the same theory here invoked of partial or complete repeal by subsequent inconsistent enactment. ${ }^{54}$ The basis of legislative amendability is to be found in the fact that the Virginia constitution and Declaration of Rights were ordinary statutory enactments which had never been submitted to the public for ratification. ${ }^{.5}$

Thus once again the authority adduced by Frankfurter and Corcoran proves equivocal at best. The Virginia summary practice indicates a restricted meaning

${ }^{53}$ Crosskey, Politics and the Constitution in the History of the United States 944-45 (1953).

${ }^{54}$ Id., at 956-57, 1062-63, 1369 n.36. Generally, consult Hamilton, The Federalist No. 78, para. 14.

357 Thorpe, op. cit. supra note 36 , at 3812 . 
of the terms "crimes" and "criminal" no more than a broad one, for partial repeal of a comprehensive provision adequately explains the existence of criminal prosecutions without benefit of jury in that state. In addition, the repealing power of the Virginia legislature was not confined to the area of the "petty offenses" of concern to Frankfurter and Corcoran. Therefore it is necessary to seek still further for the compelling exclusionary authority required to sustain the position of those authors.

Delaware declared in its constitution that "in all prosecutions for criminal offences, every man hath a right ... to a speedy trial by an impartial jury, without whose unanimous consent he ought not to be found guilty." ${ }^{966}$ This constitution was put into operation without having been submitted to the people for approval..$^{57}$ Delaware's proximity to Virginia, the succession of its constitution and bill of rights to those of the larger state by a mere three months, ${ }^{58}$ the near identity of language in the provisions of the two states, ${ }^{59}$ the promptness with which the Virginia legislature began to disregard its constitution in the autumn of $1776,{ }^{60}$ and the general attitude of the time respecting legislative supremacy ${ }^{61}$ argue that the Delaware legislature would also follow Virginia as to the alterability of its unratified constitution. Thus Delaware repeats the case of Virginia, where legislative power to eliminate the criminal jury was preserved by the statutory form of the guarantee. And therefore, if there were any evidence that summary criminal prosecutions ever occurred under the Delaware provision, ${ }^{62}$ such a practice would be explicable on the theory of repeal equally as well as on the basis of a limited understanding of "crimes" and "criminal." Consequently, Delaware falls into line with all the preceding jurisdictions which failed to substantiate unequivocally the usage essential to the FrankfurterCorcoran position.

Pennsylvania guaranteed by its constitution of 1776 that "in all prosecutions for criminal offences, a man hath a right to ... a speedy public trial, by an impartial jury of the country, without the unanimous consent of which jury he cannot be found guilty. ..." ${ }^{\prime 3}$ This state displays the same kinship to Virginia already observed on Delaware's face. The same factors noted above, including

${ }^{66}$ Del. Declaration of Rights $\$ 14$ (Sept. 21, 1776).

${ }^{57} 1$ Thorpe, op. cit. supra note 36 , at 562 .

${ }^{68}$ Compare notes 52 and 56 supra.

${ }^{59}$ Compare text at note 52 with text at note 56 supra.

${ }^{60}$ Crosskey, op. cit. supra note 53 , at 956.

${ }^{61}$ Locke, Second Essay on Civil Government, c.XI, paras. 134, 135, c.XIT, para. 150 (1690); Crosskey, op. cit. supra note 53, at 1325 n.25; Federalist No. 33, para. 6, No. 53, para. 2; Poore, Federal and State Constitutions, Charters and Other Organic Laws 1620 (1878); cf. Crosskey, op. cit. supra note 53, at 1348 n.3.

62 There is no such evidence in Frankfurter and Corcoran; nor in the briefs and opinions in the leading case of District of Columbia v. Clawans, 300 U.S. 617 (1937); nor in the extensive annotation at 75 L.Ed. 177 (1930) to District of Columbia v. Colts, 282 U.S. 63 (1930).

${ }^{63} \mathrm{~Pa}$. Declaration of Rights $\$ 9$ (Sept. 28, 1776). 
the lack of popular ratification, ${ }^{64}$ impel the same conclusion as to Pennsylvania. Moreover, the subsequent constitutional history of the state supports that conclusion by establishing that the word "criminal" actually had a comprehensive signification in the general understanding of the time.

The Pennsylvania constitution of 1790 provided that

... in all criminal prosecutions the accused hath a right to be heard by himself and his counsel, to demand the nature and cause of the accusation against him, to meet the witnesses face to face, to have compulsory process for obtaining witnesses in his favor, and, in prosecutions by indictment or information, a speedy public trial, by an impartial jury of the vicinage. . . ${ }^{65}$ [Italics added.]

By selecting out of "all criminal prosecutions" those "by indictment or information," this provision clearly demonstrates that the first class of cases is broader than the second.$^{66}$ Further, it limits its assurance of jury trial to the second, narrower category of proceedings, and makes no guarantee of jury intervention in prosecutions by complaint and arrest or by summons.

These latter two modes of criminal proceeding were traditionally ${ }^{67}$ and exclusively ${ }^{68}$ used for the "petty offenses" of Frankfurter and Corcoran, and they have been preserved for such purpose right down to the present. ${ }^{69}$ Therefore, by assuring the right to counsel, notice, etc., "in all criminal prosecutions," but trial by jury "in prosecutions by indictment or information" only, Pennsylvania in 1790 accomplished two things. It supported the view that non-jury criminal trials occurred under the prior constitution by virtue of the legislature's power of repeal, since it contradicted the alternative explanation that "criminal" bore a limited meaning. ${ }^{70}$ Furthermore, it put itself into the position

645 Thorpe, op. cit. supra note 36, at 3081; Poore, op. cit. supra note 61, at 1540 .

${ }^{65} \mathrm{~Pa}$. Const. Art. IX $\$ 9$ (1790).

${ }^{66}$ Unless, indeed, it were to be contended that "criminal" in this provision does not include offenses which might be prosecuted "by indictment or information." This triumph of restricted interpretation would deny to the man accused of the gravest offense all those protections assured his more gently charged brother, but would interfere with the present writer's theory not at all, since it would merely show a limited meaning antithetical to that urged by Frankfurter and Corcoran at 969.

674 Blackstone Comm. 279-80, 287.

${ }^{68}$ Accord: District of Columbia v. Colts, 282 U.S. 63, 73 (1930): "The offense here charged [of driving an automobile so recklessly as to endanger property and individuals] is not merely malum prohibitum, but in its very nature is malum in se. It was an indictable offense at common Iaw, ... when horses, instead of gasoline, constituted the motive power. The New Jersey Court of Errors and Appeals, in State v. Rodgers, [91 N.J.L. 212, 214 (1917)], . . . has discussed the distinction between traffic offenses of a petty character, subject to summary proceedings without indictment and trial by jury, and those of a serious character, amounting to public nuisance indictable at common law; and its examination of the subject makes clear that the offense now under review is of the latter character." (Italics added.) Cf. note 87 infra.

69 Fed. Rules Crim. Proc. 3, 4, and 5.

${ }^{70}$ The broad meaning seems not to have existed solely in the understanding of the drafters of the document, since they adjourned for six months in order that the people might examine their work. Poore, op. cit. supra note 61, at 1548; 5 Thorpe, op. cit. supra note 36, at 3092. Popular dissatisfaction would doubtless have found expression in that length of time. 
of all the jurisdictions previously discussed except Virginia and Delaware, inasmuch as those other jurisdictions also lacked an express constitutional provision assuring jury trial of the lesser crimes. Thus Pennsylvania too does not respond to the need of Frankfurter and Corcoran for authority restricting the meaning of the words "crimes" and "criminal." Rather, the state repudiates the position of those authors.

The Pennsylvania case of Byers v. Commonvealth $h^{71}$ detracts from this conclusion not at all. That case was decided in 1862 under the constitution of 1838, which contained the identical provision quoted above from the constitution of 1790. Since the offense in the case, loitering by a professional thief in a public place for an unlawful purpose, was prosecuted not by indictment or information but by complaint and arrest, of course there was no right to a jury trial. The case clearly does not fall within the jury assurance, as it was qualified in the Pennsylvania constitution. Moreover, this decision came three-quarters of a century after the Philadelphia Convention, and therefore it certainly cannot establish the existence of a narrow sense of our Constitutional language in the understanding of the Convention delegates.

Maryland, the thirteenth state in this discussion, proves uniquely troublesome. Its constitution of 1776 assured that "in all criminal prosecutions, every man hath a right ... to a speedy trial by an impartial jury, without whose unanimous consent he ought not to be found guilty."'72 The rationale already applied to Delaware and Pennsylvania with such success would ordinarily dispose of Maryland too as merely another follower of the Virginian example, since its constitution also was not submitted for popular ratification. ${ }^{73}$ Hence not the language but the form of the jury guarantee as a mere legislative enactment repealable at will would account for the state's non-jury disposition of certain crimes. However, it must be admitted that the quoted Maryland jury provision did eventually come to bear a limited signification. ${ }^{74}$

Probably this occurred because the selfsame language of the legislative constitution of 1776 was repeated in the popularly ratified constitution of $1851 .^{75}$ To the mid-nineteenth century reader the concept of a legislative amendatory power would not necessarily be obvious, for two reasons. First, the identical broad language had persisted without express alteration for three quarters of a century, through enactments restricting the right to a jury in particularly specified cases. This persistence is consistent with a limited usage of the word "criminal," and does seem to be a legislative construction of the terms of the

${ }^{71} 42 \mathrm{~Pa} .89$ (1862), discussed in Frankfurter and Corcoran 956-57.

$72 \mathrm{Md}$. Declaration of Rights $\$ 19$ (November 11, 1776).

733 Thorpe, op. cit. supra, note 36, at 1686; Poore, op. cit. supra note 61, at 817 .

${ }^{74}$ State v. Glenn, 54 Md. 572 (1880).

${ }^{75}$ And again in the constitutions of 1864 and 1867 . Poore, op. cit. supra note 61 , at 837 , $859,888$. 
jury guarantee. ${ }^{76}$ Second, the language was employed in a document called a "constitution" in both earlier and later instances.

These facts combined to thrust the formal aspect of the earlier provision into the background, and to emphasize the language as apparently the only source of the legislative dispensing power. The words were preserved unchanged, and there was no other indication comparably obvious in nature of a popular desire to modify the practice supposedly engendered by them. Accordingly the later reader might well conclude that the language did have a sufficiently narrow meaning to permit the legislature to ordain summary trial of certain crimes. Since there can hardly be a much stronger intimation of intent to express a particular idea than the adoption of terms which seem, after the passage of seven decades and more, to be already established as expressing it, the preexisting summary practice was continued under the constitution of 1851.77

All the same, Maryland supplies only dubious authority for the Frankfurter-Corcoran thesis. The first objection to this authority is that it is disqualified by the time factor. The constitutional fixing of the limited usage which ultimately prevailed in Maryland did not occur until 1851, nearly two-thirds of a century after the Philadelphia Convention. Because the final adoption of Maryland's narrow interpretation of the term "criminal" resulted from persistent exercise of the legislative dispensing power for seventy-five years, it is virtually unthinkable that near the outset of that lengthy period, while the practice was yet becoming established in the new state, the Convention delegates might have understood the Maryland provision as it was ultimately limited.

At the time the convention met in Philadelphia, the example of Virginia, close at hand, had already been loudly lamented. ${ }^{78}$ Hamilton recognized, in The Federalist, that not all the state governments acknowledged their constitutions

\footnotetext{
${ }^{76}$ But because the only evidence of such a usage is the same practice to which that usage is supposed to have given rise, the reasoning proposed in the text for the sake of plausibility suffers from circularity. This writer contends that the summary practice antedated the limited usage in Maryland, whereas the converse proposition is essential to the Frankfurter-Corcoran argument.

${ }^{77}$ See note 74 supra. No case has come to the attention of the author wherein Maryland, Pennsylvania or Virginia exercised summary criminal jurisdiction from 1776 to 1791 without specific statutory sanction. This accords with the characterization of Blackstone: "By a summary proceeding I mean principally such as is directed by several acts of parliament (for the common law is a stranger to it, unless in the case of contempts) for the conviction of offenders, and the inflicting of certain penalties created by those acts of parliament. In these there is no intervention of a jury, but the party accused is acquitted or condemned by the suffrage of such person only, as the statute has appointed for his judge." 4 Blackstone Comm. 277. Cf. Mays v. Commonwealth, $82 \mathrm{Va} .550,551$ (1886): "The legislature . . . may authorize a waiver of a jury trial by a person accused of crime, and where such authority has been conferred, a defendant who consents to be tried by the court cannot afterwards complain on the ground that he was not tried by a jury. But in the absence of such authority the court has no jurisdiction to try the accused on a plea of not guilty, otherwise than by jury; and consent cannot give jurisdiction."
}

${ }^{78}$ Crosskey, op. cit. supra note 53 , at 1062-63, 1369 n.36. 
as supreme law. ${ }^{79}$ And shortly thereafter Pennsylvania adopted its second constitution. ${ }^{80}$ This fixed a fully comprehensive usage of the word "criminal" in precise opposition to Maryland's limited meaning established more than six decades later. Moreover, Pennsylvania's broad usage was manifested before the Sixth Amendment to the national Constitution, which Amendment uses that same term, was adopted. 81

To this must be added the second objection that the narrow reading finally approved in Maryland mistook a legislative power inherent in the form of the earlier provision for one implicit in its words. Such a mistake could have escaped immediate detection and indignant denunciation only many decades after an explicit announcement of Constitutional supremacy over the legislature such as had never theretofore been made. ${ }^{82}$ Under the circumstances it seems quite inconceivable that the drafters of our national jury provisions might have been persuaded by any such argument as that an accepted narrow meaning of the word "criminal" accounted for the power of the Maryland legislature to repeal, piecemeal, the state's jury guarantee. To them it must have been altogether obvious that Maryland was doing exactly as Virginia and Pennsylvania had done.

Consequently, Maryland's summary practice can hardly be considered to require non-jury disposition of federal "petty offenses." Even if that practice had actually been predicated upon a restricted meaning of the term "criminal," this would simply reveal that one small state among the original thirteen had departed from the pattern observed by the rest. How this state could successfully impose its idiosyncrasy upon the others at the Philadelphia Convention, and again in the first Congress, is a riddle unsolved by Frankfurter and Corcoran. It is submitted that Maryland's peculiar history cannot reasonably be regarded as compelling the conclusion which those authors reach.

79 The Federalist No. 81, para. 5. Compare U.S. Const. Art. VI, para. 2.

${ }^{80}$ Pennsylvania's second constitution was completely drafted by February 26, 1790, and formally proclaimed on September 2, 1790. 5 Thorpe, op. cit. supra note 36, at 3092.

81 The first ten Amendments to the national Constitution were ratified by Pennsylvania on March 10, 1790, and the Amendments became effective November 3, 1791. 1 Thorpe, op. cit. supra note 36 , at 32 .

82 U.S. Const. Art. VI para. 2. Not until the form was fixed by ratification could the words come to be regarded as the sole vehicle to convey meaning. Only Massachusetts had a popularly ratified constitution before 1787. There the legislative power to dispense with the criminal jury persisted except in the constitutionally protected capital cases. Thus a provision having by virtue of ratification the character of "supreme law" and assuring jury trial of "all crimes" was unprecedented at the time of the Philadelphia Convention. Cf. text at note 14 supra and note 83 infra. Compare the Federalist No. 53, para. 2, which parries objection to the Constitutionally fixed biennial instead of annual elections by contrasting the English establishments of a three-year term of office subject to legislative expansion: "Where no constitution, paramount to the government, either existed or could be obtained, no constitutional security, similar to that established in the United States, was to be attempted." In short, prior to the Federal Convention constitutional flexibility of form was the rule, to which the new Federal plan constituted a singularly significant exception. 
We have now reviewed the entire historical basis of the argument for summary trial of federal "petty offenders." In each place where summary jurisdiction was exercised in the 18th century we have seen that power to dispense with the criminal jury had been reserved to the legislature, either by the language of the controlling provision, or by its statutory form. Our next task is to ascertain how the jury assurances of the national Constitution fit into this scheme.

\section{The Contrasting Federal Provistons}

A. The Language Absent from Article III.-First to meet the eye is the difference between the language of Article III and that of all the jury provisions which had previously been adopted. ${ }^{83}$ Not from the time of Magna Carta had it been constitutionally ordained that " $[t]$ he trial of all crimes ... shall be by jury." 84 Post-war unpopularity of things British may well account for the drafters' failure to employ the phraseology of the historic Charter. ${ }^{85}$ Similarly, departure from the terminology used in the various states ${ }^{86}$ might have been caused by a desire to avoid any display of favoritism among them.

However, any of several new phrasings would have satisfied such considerations and would also have clearly perpetuated the pre-Constitutional summary practice. An excellent example of such a choice appears in the Fifth Amendment to the Constitution, which declares that "[n]o person shall . . . be deprived of life, liberty, or property, without due process of law." 87 Precisely what legal process is "due" in a particular case depends upon traditional standards. ${ }^{88}$ Under such a provision, therefore, an accused person might well have been denied jury trial according to the prior custom, because a summary jurisdiction thus preserved would doubtless have comprehended the full range of crimes previously triable summarily. ${ }^{89}$ Of course, the power of disposition from the bench would have extended to more than "petty offenses" under such language..$^{90}$ But this difficulty need not be dwelt upon at the moment, since the drafters chose other words for the jury guarantee of Article III.

A second example of an alternative phrasing is discernible in the Indiana constitution of 1818 , which states that "in all criminal cases except in petit

${ }^{83}$ Curiously, Frankfurter and Corcoran do not discuss this point at all.

84 See note 1 supra.

${ }^{85}$ See text at note 15 supra.

${ }^{86}$ See notes $44,47,48,49,50,51$ supra; text at notes $46,52,56,63,72$ supra.

87 U.S. Const. Amend. V: "No person shall be held to answer for a capital, or otherwise infamous crime, unless on a presentment or indictment of a Grand Jury, except in cases arising in the land or naval forces, or in the Militia, when in actual service in time of War or public danger; nor shall any person be subject for the same offence to be twice put in jeopardy of life or limb; nor shall be compelled in any criminal case to be a witness against himself, nor be deprived of life, liberty, or property, without due process of law; nor shall private property be taken for public use, without just compensation."

${ }^{88}$ Murray's Lessee v. Hoboken Land \& Improvement Co., 18 How. (U.S.) 272 (1855).

${ }^{89}$ Katz v. Eldredge, 97 N.J.L. 123, 117 Atl. 841 (1922).

${ }^{90}$ See text at note 21 supra. 
misdemeanors, which shall be punishable by fine only, not exceeding three dollars, in such manner as the Legislature may prescribe by law, the right of trial by jury shall remain inviolate." ${ }^{\prime 1}$ (Italics added.) This provision seems to contemplate a summary jurisdiction more restricted than that proposed by Frankfurter and Corcoran. ${ }^{92}$ Ideally suited to the position of those authors, however, is the language of the North Carolina constitution of 1868. This guaranteed that "[n]o person shall be convicted of any crime but by the unanimous verdict of a jury of good and lawful men in open court. The legislature may, however, provide other means of trial, for petty misdemeanors, with the right of appeal."'93 (Italics added.)

These possibilities too were neglected by the Constitutional framers. Doubtless still others are conceivable. Their availability shows that the considerations suggested above ${ }^{94}$ as possible motivations underlying the changed terminology of Article III are far from conclusive of our problem. Such considerations would apply whether the Constitutional jury assurance be construed broadly or narrowly. Accordingly we must turn to the language actually considered and used by the drafters in order to decide whether the Constitution preserved the summary jurisdiction customary at the time.

B. The Language Present in Article III.-According to the records of the Philadelphia Convention, the drafters of Article III began by assuring a jury in "trials for criminal offences." 95 If there had been a well-established limited usage of the word "criminal" at the time the Constitution was drafted, and if the language of the first draft had been retained unmodified in Article III, there would be a rational basis on which to exclude some criminal proceedings from the jury-trial guarantee. Unfortunately for the exclusionary argument, neither of these things is true.

The only instance adduced by Frankfurter and Corcoran of a clearly restricted meaning of "criminal" occurred by mistake in the state of Maryland in the latter half of the 19th century, much too late to be helpful here. ${ }^{96}$ Blackstone's observation on the point is at best equivocal. He noted an occasional narrow sense of "crimes" when used as a noun, and not when employed in its adjective form. ${ }^{97}$ Disregarding this formality ${ }^{98}$ does not improve

\footnotetext{
${ }^{91}$ Ind. Const. Art. I, $\$ 5$ (1816). Note that the term "criminal" in this provision inchudes "petit misdemeanors."

${ }_{92}$ The precise extent of the Frankfurter-Corcoran "petty offenses" is uncertain, although they might be distinguishable from felonies on the ground of "the minor quality of the misconduct." Frankfurter and Corcoran 980. Their vague definition receives fuller discussion in the text at note 165 infra.

${ }^{93}$ N.C. Const. Art. I, $\$ 13$ (1868). Note that the term "crime" in this provision includes "petty misdemeanors."

${ }^{94}$ See text following note 84 supra.

95 2 Farrand, Records of the Federal Convention 144 (1937).

${ }^{96}$ See text following note 72 supra.

${ }^{97}$ See note 26 supra.

${ }^{98}$ As did Alexander Hamilton, Federal Convention delegate. In The Federalist No. 83, para. 4, Hamilton referred to Article III's assurance of a jury in the "trial of all crimes" as "a
} 
matters, since the noun "crimes" was also used generally with a broad meaning. ${ }^{99}$ Thus any limited sense of the word would be plain only where a contrasting term, like "misdemeanors," appeared in the context. No such contrasting term is to be found in Article III or its preliminary drafts. Finally, the Pennsylvania constitution of 1790 discloses a nearly contemporaneous comprehensive usage of "criminal."100 It cannot be entirely without significance that this broad usage was manifested in the same state where the Constitutional Convention had so recently met. Palpably, the evidence fails to justify the conclusion that the word "criminal" was generally understood in a restricted sense. On the contrary, it renders the existence of any such understanding highly dubious.

The ultimate refutation of the restricted-meaning argument was made by the rramers themselves when they interpolated before the "criminal offences" of their original draft the adjective "all."101 If Blackstone's observation just mentioned had evoked the merest suspicion that the first-chosen words might have been used in a narrow sense, it must be dispelled by this most inclusive modification. For even if "criminal" standing alone might have meant less than all penal offenses, which is no better than a doubtful supposition, it could not have continued to mean less than all of them after this addition of the word "all."

In fact, the inclusion of this adjective in the Constitutional guarantee requires a showing by federal summary trial proponents that "criminal" had a limited meaning not only occasionally, but universally. One arrives at this view by reasoning as follows: As used without modification, "criminal" must have conveyed either a broad or a narrow understanding. If broad, "all" may have been added as a clarifying measure. If narrow, "all" may have been added as an amplifying measure. In either event, the change does not minimize but maximizes whatever meaning is contained in "criminal." Therefore, "criminal" as maximized must refer to less than all crimes, if any are to continue subject to summary prosecution. But the broad, or maximum, meaning of "crimes" and "criminal" incontestably includes all felonies, misdemeanors and "petty offenses." ${ }^{102}$ Consequently, it is extremely difficult to see how any summary practice could have been perpetuated under the promise of a jury in "trials for all criminal offences." (Italics added.)

The final change to "trial of all crimes"103 makes it no easier to comprehend any such perpetuation. There is even less evidence (if that is possible) that "crimes" was usually understood in a limited sense than there was to show such

provision obliging the legislative power to commit the trial of criminal causes to juries." (Italics added.) Hamilton no doubt discerned the difference in form between "crimes" and "criminal," but evidently none in meaning.

${ }^{99} \mathrm{E}$ g., 4 Blackstone Comm. 1-2.

${ }^{100}$ See text following note 65 supra.

1012 Farrand, op. cit. supra note 95, at 173, 187.

102 See note 99 supra; cf. notes 91 and 93 supra.

${ }^{103} 2$ Farrand, op. cit. supra note 95 , at $433,438,576,601$; note 1 supra. 
understanding of "criminal." At least we had the singular case of Maryland to discuss in connection with the latter term..$^{104}$ As to the former there is only Blackstone. But the narrow usage of "crimes" noted by Blackstone is not a sound authority, since Blackstone himself impeaches it as improper and gives full recognition to the broad meaning of the word. ${ }^{105}$ Furthermore, the presence of the modifier "all" maximizes the content of "crimes" just as it did "criminal" in the earlier draft. Accordingly, the only conclusion which seems reasonably proper is that the change from "trials for all criminal offences" to "trial of all crimes" does not perpetuate the summary jurisdiction of pre-Constitutional days.

If the language of Article III does not preserve the whole antecedent summary practice, it could not very well preserve that part of it which is the concern of Frankfurter and Corcoran. The discrepancy between the only narrow meaning of "crimes" and "criminal" which those authors were able to propound, and the "petty offenses" which they propose to exclude from the signification of those terms, has been noticed before. ${ }^{106}$ No less wide now than formerly yawns the gulf between the felonies once triable summarily ${ }^{107}$ and the fairly humble transgressions called "petty offenses."10s Thus it appears that the more modest the exception sought to be carved out of the Constitutional language, the more the difficulties which intervene. Logical simplicity requires the conclusion that the words of Article III preserve any part of the prior summary practice no more than the while.

C. Amendment VI.-Adoption of the Constitutional Amendments in 1791 harmonizes fully with the foregoing analysis. Jury trial in "all criminal prosecutions"109 seems co-extensive with the jury "trials for all criminal offences" which had evolved into jury "trial of all crimes." 110 This writer agrees with Frankfurter and Corcoran that, broad or narrow, "the scope of trial by jury guaranteed by the Sixth Amendment is identical with the scope of jury trial in Article III."'III The reason for repeating the jury assurance is to be found in the palliative purpose of the Bill of Rights. ${ }^{112}$ A comprehensive reading of Amendment VI is also fortified by the broad usage of the term "criminal" established by the Pennsylvania constitution of 1790 . Consequently, it is evident that

104 See text following note 72 supra.

${ }^{105}$ See note 26 supra; text at note 99 supra.

106 E.g., text at notes 20 and 90 supra.

${ }^{107}$ See note 21 supra.

${ }^{108}$ See note 92 supra.

${ }^{109}$ See note 2 supra.

${ }^{110}$ See note 1 supra.

III Frankfurter and Corcoran 971. Accord: 5 Moore's Federal Practice 73 (1951).

112 Crosskey, op. cit. supra note 53, at 678-79; Frankfurter and Corcoran 970. See also text at note 191 infra. 
Article III's ostensible repudiation of the English summary jurisdiction was reaffirmed by the Sixth Amendment.

D. The Binding Form of the Federal Provisions.-Though the Constitutional language does not allow for prosecution of "petty offenses" without a jury, the possibility remains that the form of the guarantees permits their repeal by subsequent inconsistent legislation. This we saw to be the case in Virginia and the two or three states which followed its example. However, the constitutions of all of those states were unratified and were in consequence regarded as ordinary legislative enactments. The national Constitution differs vitally by reason of its popular ratification ${ }^{113}$ and its express provision making it "the supreme Law of the Land."'114

Thus the Virginia example is no precedent for any comparable national practice. The state legislatures were not, whereas the nation's Congress is, bound to respect the constitutional jury guarantee. Hence it is clear that on their face the jury assurances of Article III and Amendment VI do not comport in any way with the prior scheme of summary prosecutions under English, colonial and initial state law. Rather, they appear to constitute a complete departure from that scheme because their language purports to abrogate the summary practice instead of perpetuating it and their binding form permits no legislative modification.

E. Records of Debates and the Intent of the Drafters.-The textual changes just described may have been accompanied by debates among the Convention delegates and the congressmen of 1789. But as Frankfurter and Corcoran concede, ${ }^{115}$ the records are scanty and barren of material either to corroborate their restricted reading of the jury guarantees, or to contradict this writer's broad interpretation thereof. This could be due to deficiency in recording and preservation as well as to dearth of debate. However, Frankfurter and Corcoran urge that the silence of the records assures a general understanding among the delegates and the congressmen that the language ultimately chosen by them preserved the antecedent summary practice, at least insofar as that practice applied to "petty offenses." 116

If lack of recorded argument indicates any more than lack of records, it is reasonable to suppose that it suggests lack of debatable issues, for argument would be obviated by agreement, to be sure. Therefore it is easily conceded that want of debate might connote some kind of general agreement on the effect of the jury provisions. An examination of the available historical materials suggests, however, that the inference of Frankfurter and Corcoran is no more tenable than the contrary conclusion that if any general understanding of the Constitutional jury provisions existed, it was that they abolished the prior summary practice so far as the federal government was concerned.

113 Beard and Beard, op. cit. supra note 37, at 135-37.

114 U.S. Const. Art. VI, para. 2.

115 Frankfurter and Corcoran 968.

116 Id, at 968-70. 
It must be borne in mind that our Constitution was the fruit of a revolution, and that the inherent tendency of rebellion is to pursue extremes magnified in value by the preceding constraint and denial; in a word, overcompensation. Ire had been roused in the colonies by English inroads upon the right to jury trial, ${ }^{117}$ and the common trend in the states during their early years of independence was to enshrine the institution, even though summary criminal trials did occur to a limited extent.118

Thus in the decade or so before the Philadelphia Convention more than half119 of the thirteen states adopted constitutional provisions of this type: "Nor can any man be justly deprived of his liberty except by the laws of the land, or the judgment of his peers." ${ }^{120}$ While this language, modeled after Magna Carta, ${ }^{121}$ permitted subsequent legislative diminution of the right to a criminal jury, its immediate effect was to establish the right in all cases, unless and until the legislature decided to direct otherwise. ${ }^{122}$ In other words, the provision abolished the previous summary jurisdiction but reserved to the legislatures the power to re-establish it and even to expand it in the course of time. Consequently, the idea of abolition could not have been utterly alien to the minds of the Convention delegates. Pennsylvania, the very state wherein they met, had explored the process of abrogation and piecemeal revival of the summary practice. ${ }^{123}$

Some states exhibited even more respect by constitutionally announcing that judgment of a man by his peers in a jury trial was one of the greatest securities of the lives, liberties and estates of the people, ${ }^{124}$ and variously denominating the right "inestimable"125 and "sacred." 126 In the campaign to ratify the new national Constitution the attitude of the time was epitomized as follows:

117 Declaration of Independence (1776): "... The history of the present King of Great Britain is a history of repeated injuries and usurpations, all having in direct object, the establishment of an absolute Tyranny over these States. To prove this, let Facts be submitted to a candid world. ... He has combined, with others, to subject us to a jurisdiction foreign to our Constitution, and unacknowledged by our laws; giving his Assent to their Acts of pretended Legislation ... . for depriving us, in many cases, of the benefit of Trial by Jury. ..."

- 118 See note 13 supra.

${ }^{119}$ Md. Declaration of Rights $\$ 21$ (Aug. 14, 1776); Mass. Declaration of Rights Art. XUI (Mar. 2, 1780); N.H. Bill of Rights Art. 15 (June 2, 1784); N.Y. Const. \$13 (Apr. 20, 1777); Pa. Declaration of Rights $\S 9$ (Sept. 28, 1776); Va. Declaration of Rights $\S 8$ (June 12, 1776); S.C. Const. $\$ 41$ (Mar. 19, 1778). Accord: IIl. Const. Art. $8 \$ 8$ (1818); Ky. Const. Art. $10 \$ 10$ (1799); Me. Declaration of Rights $\$ 6$ (1818); Mo. Const. Art. $13 \$ 9$ (1820); Vt. Declaration of Rights Art. 10 (July 4, 1793).

${ }^{120} \mathrm{~Pa}$. Declaration of Rights $\$ 9$ (1776). $\quad{ }^{121}$ See text at note 15 supra.

120 See text at note 129 infra. Cf. The Federalist No. 81, the antepenultimate paragraph, fifth sentence.

${ }^{123}$ See text following note 69 supra; Frankfurter and Corcoran 955-56, 996-98.

${ }_{124}$ Del. Declaration of Rights $\$ 13$ (1776); Md. Declaration of Rights $\$ 18$ (1776). Accord: N.C. Declaration of Rights $\$ 14$ (1776).

125 N.J., Const. $\$ 22$ (1776).

${ }^{126}$ Mass. Declaration of Rights Art. XV (1780); N.C. Declaration of Rights $\$ 14$ (1776); N.H. Bill of Rights Art. 20 (1784); Va. Declaration of Rights $\$ 11$ (1776). Accord: Ky. Const. Art. $10 \$ 6$ (1799); Vt. Declaration of Rights Art. 12 (1793). 
The friends and adversaries of the plan of the [Federal] convention, if they agree in nothing else, concur at least in the value they set upon the trial by jury; or if there is any difference between them it consists in this: the former regard it as a valuable safeguard to liberty; the latter represent it as the very palladium of free government. ${ }^{127}$

Though this comment was made in discussing the effect of the Article III jury guarantee, the point at issue in the discussion was the right to jury trial in civil cases. To pursue this point may carry us slightly afield from our investigation of the contemporary attitude toward the summary criminal practice. Nevertheless, because of the close analbgy between civil and criminal jury trials as opposed to civil and criminal bench trials, the popular enthusiasm for the civil jury will be examined for the sake of the light it may shed on our related inquiry.

The adversaries of the Federal plan had argued that the explicit criminal jury assurance of Article III abolished jury trial of civil causes by negative implication. Friends of the plan found a forceful spokesman in Alexander Hamilton, New York delegate to the Philadelphia Convention. He laid this phantom to rest with these words:

[L]et me ask if it is consistent with common sense to suppose that a provision obliging the legislative power to commit the trial of criminal causes to juries is a privation of its right to authorise or permit that mode of trial in other cases? Is it natural to suppose that a command to do one thing is a prohibition to the doing of another which there was a previous power to do and which is not incompatible with the thing commanded to be done? If such a supposition would be unnatural and unreasonable, it cannot be rational to maintain that an injunction of the trial by jury in certain cases is an interdiction of it in others. ${ }^{128}$

Hamilton's conclusion that the civil jury was not abolished finds support in both precedent and policy. The case of Blankard v. Galdy ${ }^{129}$ had long since established the common-law rule that an alteration in the form of a country's government leaves its existing law unchanged except to the extent modified expressly or by necessary implication. The principle that "the common-law of England, as well as so much of the statute law as have been heretofore practiced in this colony, shall still remain in force until they shall be altered by a future law of the legislature; such parts only excepted as are repugnant to the rights and privileges contained in this charter"130 was given utterance in more than one state constitution as a legislative paraphrase of the Blankard holding. ${ }^{131}$

127 The Federalist No. 83.

${ }^{128}$ The Federalist No. 83. Hamilton also remarks on the great practical difficulties of making a uniform provision for civil juries and the choice of the Convention to leave the matter for Congressional regulation. As to these matters he is well substantiated by the comments of other delegates. 2 Farrand, op. cit. supra note 95 , at 587, 628; 3 id,. at 101, 150, 163-4, 167-8, $250,298,309,332,349,352$.

${ }^{129} 2$ Salkeld 411 (1693). Accord: Crosskey, op. cit. supra note 53, at 657.

130 N.J. Const. $\$ 22$ (1776).

131 Ibid.; Del. Declaration of Rights $\$ 25$ (1776); N.Y. Const. $\$ 35$ (1777). Cf. Md. Declaration of Rights $\$ 3$ (1776); N.H. Const. of 1784, Part II; S.C. Const. $\$ 34$ (1778); Crosskey, op. cit. supra note 53 , at $593-99$. 
The implication that trial by jury in civil cases was abolished seems clearly not a "necessary" one under this rule.

Moreover, the Preamble to the new Constitution specified the establishment of justice among the ideals sought to be realized under the plan of the Convention. No doubt this goal was to be attained "according to the course of the common law, "'132 as that law was generally effective in America. ${ }^{133}$ But inasmuch as trial by jury typified the common-law ${ }^{134}$ proceeding, to abolish the jury in civil cases would not be to establish justice in accordance with the prevailing standard of the time, but to defeat that much-desired end. Had not the English abolition of the jury, even though incomplete, recently been denounced as tyrannical ${ }^{135}$ Did not every one of the thirteen states make substantial provision for jury trial, if not by written constitution, ${ }^{136}$ then by well-established practice? ${ }^{137}$ Considering all this, it is a matter of no wonder for Hamilton to find that all "concur at least in the value they set upon the trial by jury"138 as a minimum guarantee of justice; it would have been astonishing had he encountered dissent.

Hence the view is justified that American enthusiasm for the jury was high in the final quarter of the 18 th century. In Georgia this fervor went so far that the jury was made "judges of law, as well as of fact."139 Precisely because manpoor communities could ill afford to keep producers long in jail, ${ }^{140}$ the passion

${ }^{132}$ N.Y. Const. $\$ 41$ (1777); cf. Md. Declaration of Rights $\$ 3$ (1776).

${ }^{133}$ Crosskey, op. cit. supra note 53, at 599.

${ }^{134}$ Common-law in the sense which excludes the equity and admiralty jurisdictions. Consult Crosskey, op. cit. supra note 53 , at $870-77$.

135 See note 117 supra.

${ }^{136}$ Del. Declaration of Rights $\$ 13$ (1776); Ga. Const. $\$ 61$ (1777); Md. Declaration of Rights $\$ 3$ (1776); Mass. Declaration of Rights Art. XV (1780); N.C. Declaration of Rights $\$ 14$ (1776); N.H. Bill of Rights Art. 20 (1874); N.J. Const. \$22 (1776); N.Y. Const. \$41 (1777); Pa. Const. c. II, $\$ 25$ (1776); S.C. Const. Art. IX, $\$ 6$ (1790); Va. Declaration of Rights $\$ 11$ (1776).

${ }^{137}$ Connecticut had no written constitution, but a contemporary account informs us that "[t]he superior and county courts try matters of fact by a jury, according to the course of the common law." The Constitutions of the Several Independent States of America 54 (2d ed., Boston, 1785). The Federalist No. 83 reviews the extent of the right to jury trial in New York, New Jersey, Pennsylvania, Delaware, Maryland, Virginia, North Carolina, South Carolina and Georgia and observes that "[i]n Connecticut ... the trial by jury extends in practice further than in any other State yet mentioned." (Hamilton's emphasis.)

Rhode Island too was without a written constitution. Crosskey, op. cit. supra note 53, at 1349. However, in Trevett v. Weeden (R.I., 1786), it was argued that legislation providing for recovery of a penalty was inconsistent with the state's unwritten constitution in denying jury trial. Crosskey, op. cit. supra note 53, at 965-68. The argument would not likely have been made without a practice to support it. And Hamilton adds, after the comment just quoted concerning the extensive use of juries in Connecticut, "Rhode Island is, I believe, in this particular, pretty much in the situation of Connecticut."

${ }^{138}$ The Federalist No. 83.

${ }^{139} \mathrm{Ga}$. Const. $\$ 41$ (1777). Accord, as to criminal cases: Ind. Const. Art. I, $\$ 19$ (1851); Md. Const. Art. 15, $\$ 5$ (1851).

${ }^{140}$ See Frankfurter and Corcoran 936. 
for the protection of a jury in civil controversies could have exceeded but little, if at all, the fervor for its criminal counterpart. The principle of Blankard v. Galdy would require diminution in the use of the criminal no more than of the civil jury, and the Preambular policy aim of justice would favor the criminal jury no less than the civil. Accordingly, it seems likely that the respect of the Convention delegates for jury trial of criminal cases was not much, if any, lower than their regard for civil jury trials.

Explicit Constitutional requirement of civil jury trial was considered impracticable because of the diversity among the states in distinguishing between, and in using the jury in connection with, the admiralty, equity, probate and common-law jurisdictions. ${ }^{141}$ No such conflict existed as to use of the criminal jury. The only differences in that area were minor ones of degree presented by the varying extent of revival or preservation of summary prosecutions in the states. The high popular sentiment made inclusion of a jury assurance in the proposed Constitution a practical necessity. A limited provision might antagonize the people and thus be worse than none at all. On the other hand a broad guarantee would provide a solid foundation on which to erect a liberal tradition as the nation matured. Consequently, the drafters followed the simplest course open to them and guaranteed jury trial of "all crimes."

Had this provision been thought to have only a restricted meaning, it could hardly have appeased the popular ardor which provoked it. The Americans had dissolved their ties to England because they wanted a change, and specifically because they wanted a change in the previously limited scope of jury trial. To offer them a mere perpetuation of the same qualified promise which had just been condemned to a bloody death in the Revolutionary war was not a course plausibly to be followed by men anxious to perfect the uneasy union of the states. Rather, an absolute commitment was well calculated to gain popular approval and assure political growth. Especially appealing must have been an abrogation of summary proceedings like that which had recently taken place in over half the states. ${ }^{142}$ The only difference from the state provisions was that no power of detraction from the jury guarantee was reserved to Congress.

Such an understanding among the Convention delegates would not have been unreasonable. Its existence is supported by Hamilton's description of the Article III guarantee as "most ample." 143 This characterization not only bolsters the contention made here but also tends to refute the FrankfurterCorcoran position that the opposite view, reading the jury assurance as limited and preservative only, was universally held. Consequently, it cannot be inferred that the silence of the records excludes all possibilities but perpetuation of summary prosecutions under the Federal government. Instead, that silence must be recognized as no less equivocal than all the other authority adduced by Frankfurter and Corcoran.

141 See note 128 supra. 142 See text at note 119 supra.

143 The Federalist No. 83 quoted in text at note 185 infra. 
F. The Bolmes Theory of Documentary Interpretation.-Notwithstanding the ostensible rejection of the prior summary jurisdiction by the Constitutional language and form, and the great historical likelihood that this result was desired by the drafters, the bare possibility remains that the framers really did not mean to abolish non-jury criminal prosecutions. In other words, the last resort of the proponents of federal summary jurisdiction is the possibility of a mental reservation or oversight on the part of the drafters.

Such a contention would present a problem of documentary interpretation. So august a modern jurist as Oliver Wendell Holmes, Jr., has pointed out the way to solve this kind of problem. ${ }^{144}$ The use of writings, Holmes declares, is justified only to the extent that writers' purposes are given effect. A principal purpose of writing is to externalise the writer's intention or state of mind, for the sake of preserving it accurately and of communicating it clearly. Because this externalisation is a prime cause of writing, to delve into the writer's subjective intent is to defeat one of his major purposes. Therefore none but an objective standard of interpretation ought to be applied to a writing to discover the intent sought to be expressed therein.

Objective interpretation of documents prefers form to content in accord with the intent manifested in the ceremonial act of writing. But this is merely to confer a legal sanction on the maxim that actions speak louder than words. Who writes by that act makes content secondary to form, because he assigns to the document the function of expressing his intent. Thus we are committed to the rule that a document speaks as of a time no earlier than when it is written; committed by our policy of encouraging use of writings by effectuating their purpose; and committed by the writer's reliance on such policy to externalize his state of mind, so that it may be preserved with certainty and communicated with reliability.

These same considerations also commit us to the rule that a document speaks as of a time no later than when it is written. Lacking such a commitment, we might substitute for its objective meaning the interpretation of intervening readers, and thereby defeat the objects of preservation and communication which initially prompted the writing process. Consequently, inquiries beyond the face of the document are equally foreclosed to us by our policy of encouragement, whether they explore anterior or posterior states of mind.

This rationale is the basis of the objective standard formulated by Holmes for interpreting writings: "we ask, not what this man meant, but what these words would mean in the mouth of a normal speaker of English, using them in the circumstances in which they were used. . . "145 (Italics added.) This standard rejects individual departures from general understanding where objective indications of such departure are absent from the document. In turn, it gives (1920).

144 Holmes, The Theory of Legal Interpretation (1899), in Collected Legal Papers 203-209

145 Id., at 204. 
rise to particular rules, some of which are also enunciated by Holmes. "In the case of a statute," he writes, "[w]e do not inquire what the legislature meant; we ask only what the statute means." 146 Again, departures from general usage are rejected unless evident on the face of the writing. In other words, it is improper statutory construction to allow an unexpressed legislative intent to defeat or modify an expressed intent, although the unexpressed intent be known by some independent and reliable means. A fortiori, in no event may an intention which is merely conjectured or assumed prevail over the one actually expressed.

Turning from a statute to a ratified constitution, we find that the same rules apply. By definition such constitution would be the highest law of the state, against which all other laws would be measured. ${ }^{147}$ If the need for certainty in preserving and clarity in communicating the writer's state of mind requires objectivity in statutory construction, so much more important is the requirement of objectivity in constitutional interpretation. Accordingly, the objective standard of Holmes guides us in reading both statutes and constitutions.

Application of the Holmes objective standard of interpretation to our national Constitution produces salutary results. One of these results is that distortion of Constitutional law by subsequent abuse is prevented. In the area of legislation Holmes specifically recognizes that a statute merely declaratory of the meaning of a prior enactment is retrospective. ${ }^{148}$ Indeed, to permit a government, under the guise of interpretation, to make an authoritative reading of its constitution and statutes not restrained by an objective standard but dictated by whim is, at best, to invite social chaos. At worst, it opens the door to absolute dominion by a kind of bootstrap usurpation. ${ }^{149}$

An equally wholesome result is that desired changes from antecedent custom can be rendered effective. After all, there must be some limit to the reading of history into the language of the law, for otherwise it will be impossible to escape the mistakes of the past. Holmes very reasonably fixes that limit at the general usage of the language at the time and place of the utterance. Under his authority, therefore, any mental reservation or oversight on the part of the framers would be incompetent to affect the objective interpretation of the language they used.

All readers of the Constitution are bound, according to the reasoning of Holmes, to understand it on the basis of the general usage of its language at the time and place expressed. The author has demonstrated a comprehensive con-

${ }^{146}$ Id., at 207.

${ }^{147}$ See Hamilton, The Federalist No. 81 para. $5:$ " [T] ard of construction for the laws, and ... wherever there is an evident opposition, the laws ought to give place to the Constitution. But this doctrine is not deducible from any circumstance peculiar to the plan of the convention, but from the general theory of a limited Constitution; and as far as it is true, is equally applicable to most, if not to all the State governments." Cf. U.S. Const. Art. VI paragraph 2.

${ }^{148}$ Holmes, op. cit. supra note 144 , at $208 . \quad{ }^{149}$ See notes $156,168-69$ infra. 
temporary usage of the words "crimes" and "criminal." Frankfurter and Corcoran have put forth no evidence of any general understanding of these terms corresponding to the more or less restricted summary practice which they favor. The necessary conclusion is that jury trial of all crimes, including "petty offenses," is required by the Constitution. That is what the drafters said, and what they said we are bound to heed; whether or not they actually realized and intended all the implications is immaterial.

Having given due consideration to Holmes' theory of documentary interpretation, to the records of the Philadelphia Convention and of the first Congress, and to the actual language of the Constitution, we can dispose finally of the question raised above at the end of section II: how do the Constitutional jury guarantees square with the pre-existing summary criminal practice? Palpably, the answer is that they depart completely from the antecedent custom. PreConstitutional history reveals not only the existence of the summary jurisdiction, but also a legislative power to create and extend it given by way of language or amendable form in the governing provision. It has just been shown that no such power is to be found in the words or form of our Constitution, and that this deficiency is remedied neither by the records of debate nor by accepted theory of documentary interpretation. Consequently, the ancient practice cannot logically or lawfully be put into force under the Constitution, even if a resurrection of summary proceedings in the federal courts be considered desirable. That the drafters were prudent to plan for this result will become apparent in the succeeding section, where we shall consider policy factors in relation to non-jury prosecutions.

\section{Policy Aspects of Federat Summiry Trials}

A. Public vs. Individual Interest.-Two arguments in favor of summary procedure may be gleaned from the Frankfurter-Corcoran article. The first of these is aptly stated in their quotation, with approval, from the New Jersey case of Katz v. Eldredge:

[T] he convenience and benefit to the public resulting from a prompt and inexpensive trial and punishment of violations of petty and trivial police power regulations are more important than the comparatively small prejudice to the individual resulting from his being deprived of the safeguard . . o of trial by jury. . . . ${ }^{150}$

Thus to place public convenience above individual interest is to invert the scale of values which generated our society. Governments are instituted in response to individual needs. The institution is brought into existence to serve the individuals, not the converse.

Such is clearly the case in the United States, where "the supreme Law of the Land"151 was ordained to "secure the Blessings of Liberty" 152 to American citizens. One of the "self-evident" truths recognized in the Declaration of

15097 N.J.L. 123, 151, 117 Atl. 841, 852 (1922), discussed in Frankfurter and Corcoran 953.

151 U.S. Const., Art. VI, para. 2.

152 U.S. Const., Preamble. 
Independence by the Founding Fathers of this nation is that the right of all men (including accused criminals) to liberty is "inalienable." Another is that governments are instituted among men to secure the right of liberty, inter alia. A third is that the consent of the governed is the sole source of just governmental power. ${ }^{153}$ Under this analysis, governmental inroads upon personal liberty by abrogation of the right to a criminal jury are improper, unjust, and even tyrannical. Since the right to liberty is inalienable, the power to invade it cannot, by definition, be derived from the consent of the governed.

This highly sensitive concern for individual freedom in America was not a battlefield casualty in the Revolution. Rather it survived to receive explicit recognition in the new nation's Constitution. ${ }^{154}$ Nevertheless, despite this promising history, summary trial proponents find public convenience "more important"165 than the individual liberty to secure which so many American patriots fought and died. Such an attitude received acute criticism from Blackstone in his commentaries on the value of the criminal jury:

[T]he liberties of England cannot but subsist, so long as this palladium remains sacred and inviolate, not only from all open attacks, (which none will be so hardy as to make) but also from all secret machinations, which may sap and undermine it; by introducing new and arbitrary methods of trial, by justices of the peace, commissioners of the revenue, and courts of conscience. And however convenient these may appear at first, (as doubtless all arbitrary powers, well executed, are the most convenient) yet let it be again remembered, that aelays, and little inconveniences in the forms of justice, are the price that all free nations must pay for their liberty in more substantial matters; that these inroads upon this sacred bulwark of the nation are fundamentally opposite to the spirit of our constitution; and that, though begun in trifles, the precedent may gradually increase and spread, to the utter disuse of juries in questions of the most momentous concern. ${ }^{156}$ [Blackstone's emphasis.]

This eloquent denunciation of piecemeal abrogation of the criminal jury applies in the United States as well as in England. But here such inroads upon personal liberty are not only opposed to the spirit of the Constitution; they are also contrary to its letter. Therefore revival in our federal courts of summary jurisdiction pursuant to the Frankfurter-Corcoran thesis can hardly be justified as a general convenience to the public.

Particularizing public convenience in terms of court congestion and burdensome jury duty adds no persuasiveness to the contention.

To inflict upon the accused, summarily, imprisonment in a common jail for [three months], and at the same time to deny him of right an appeal to a court of record, is a matter which cannot be whistled down the wind with the statement that court busi-

${ }^{153}$ Declaration of Independence (1776).

154 E.g., Amendment VI promises the individual "accused" a jury trial "in all criminal prosecutions." See note 2 supra.

${ }^{155}$ See note 150 supra.

${ }^{156} 4$ Blackstone Comm. 343-4. 
ness must go on, that dockets must be cleared, or that the requirements of jury service should not be expanded to the loss of the citizen in his private affairs. ${ }^{157}$

The congestion problem is far better solved by augmenting the judiciary. Two or three weeks of jury service in a lifetime do not impose any unreasonable burden upon the citizen; they amount only to a small premium on his insurance against summary conviction of a federal crime. If summary jurisdiction proponents can find no better policy arguments than these in favor of their position, they have a sorry case indeed.

B. Relieving Oppressed Defendants.-A second argument for federal summary prosecutions arises from the circumstance that congested jury dockets may sometimes prevent immediate trial of accused criminals. ${ }^{158}$ The contention amounts to this: fulfilment of the Constitutional requirement that criminal trials be speedy requires abrogation of the jury requirement because under present conditions it is impossible to satisfy both requirements.

This proposition is vulnerable on several grounds. ${ }^{159}$ However, assuming that it has merit, why should accused "petty offenders" be selected to bear the whole burden? The benefit of accelerated jury trial is limited to alleged felons and misdemeanants. ${ }^{160}$ By way of good time allowance ${ }^{161}$ and eligibility to parole ${ }^{162}$ such individuals already enjoy privileges denied the "petty offender." These privileges open the prison doors for misdemeanants under minimum sentence in about one third of the time "petty offenders" may be required to serve. Felons may obtain conditional release in little more than half of the "petty offender's" maximum period of confinement. ${ }^{163}$

In this situation which class of defendants is most oppressed? Clearly the risk of a disproportionately severe punishment already oppresses the least

${ }^{157}$ Clawans v. District of Columbia, 84 F.2d 265, 269 (1936), aff'd on other grounds, 300 U.S. 617 (1937). Cf. 4 Blackstone Comm. 277-8.

${ }^{158}$ See Frankfurter and Corcoran 920, 934.

${ }^{159}$ E.g., (1) The Constitution establishes no priority as between these requirements; (2) if there is any priority it would favor jury in tervention, an absolute matter, over speed, a relative matter; (3) waiver of the speed requirement should be no less permissible than waiver of the jury requirement; (4) jury trial is waived in so many cases that no actual conflict arises between the two requirements in the relatively fewer cases remaining. Cf. Holtzoff, A Criminal C.ase in the Federal Courts, Fed. Rules Crim. Proc. \& Tit. 18 U.S. Code, 1, 17 (West, 1955).

${ }^{160}$ For further definition of these terms see note 5 supra.

16162 Stat. 853 (1948), 18 U.S.C.A. $\$ 4161$ (1951).

16262 Stat. 854 (1948), 18 U.S.C.A. $\$ 4202$ (1951).

${ }^{163}$ After serving a possible six-month jail sentence, an impecunious defendant might still be required to remain imprisoned until his fine (up to $\$ 500$ ) is paid. 62 Stat. 837 (1948), 18 U.S.C.A. $\$ 3565$ (1951). Such additional period of incarceration can be limited to 30 days if the prisoner is poor enough (and informed enough) to invoke 62 Stat. 838 (1948), 18 U.S.C.A. $\$ 3569$ (1951). Thus imprisonment of a "petty offender" may endure, or even exceed, seven months. By contrast, more heinous offenders are eligible to parole after serving one third of their sentences. Thus a misdemeanant sentenced to 27 weeks may obtain conditional release after 9 weeks, and a felon sentenced to a year and a day may be paroled in about 4 months. 
culpable offenders. ${ }^{164}$ Why should that oppression be increased by denial of jury trial? Furthermore, where is the evidence that such increased oppression will produce any real benefit, and that such benefit is needed? To this writer it seems that those who wish to relieve oppressed defendants should be arguing not in favor of but against summary prosecutions.

C. Certainty in the Lar.-One of the most disturbing aspects of the Frankfurter-Corcoran position is the vagueness with which those authors define "petty offenses." These crimes are "acts ... which [do] not offend too deeply the moral purposes of the community, which [are] not too close to society's danger, and [are] stigmatized by punishment relatively light." ${ }^{165}$ The ultimate responsibility for applying this uncertain standard to specific instances rests upon the Supreme Court. ${ }^{166}$ Like all relative criteria those enumerated are susceptible to fluctuation, and consequently no one can say in advance of Supreme Court decision whether a particular offense warrants jury trial..$^{167}$ Moreover, even after a decision has been reached there can be no reliance on it, since the extreme flexibility of the Frankfurter-Corcoran standard poses a constant threat of reversal.

Such uncertainty in the state of the law was a favorite topic of discussion in the 17 th and 18th centuries. In the general opinion of the time the law was understood to provide a standing rule of conduct for the community, and legal uncertainty was considered an evil so vicious as practically to threaten the dissolution of free society. Thus in 1690 John Locke had said:

Absolute arbitrary power, or governing without settled standing laws, can neither of them consist with the ends of society and government, which men would not quit the freedom of the state of Nature for, and tie themselves up under, were it not to preserve their lives, liberties, and fortunes, and by stated rules of right and property to secure their peace and quiet. ... And, therefore, whatever form the commonwealth is under, the ruling power ought to govern by declared and received laws, and not by extemporary dictates and undetermined resolutions, for then mankind will be in a far worse condition than in the state of Nature if they shall have armed one or a few men with the joint power of a multitude, to force them to obey at pleasure the exorbitant and unlimited decrees of their sudden thoughts, or unrestrained, and till that moment, unknown wills, without having any measures set down which may guide and justify their actions. For all the power the government has, being only for the good of the society, as it ought not to be arbitrary and at pleasure, so it ought to be exercised by established and promulgated laws, that both the people may know their duty, and be

164 The text assumes a jail sentence eliminating the possibilities of time off for good behavior and release under supervision is retributive rather than rehabilitative.

${ }^{165}$ Frankfurter and Corcoran 980-81.

${ }^{166}$ Id., at 982 . The burden is being retained on an uncomfortable case by case basis. United States v. Kronheim, 80 A.2d 280, 281 (Mun.Ct.App.D.C., 1951).

${ }^{167}$ Note the peculiar history of District of Columbia v. Clawans, 300 U.S. 617 (1937): summary trial; reversed on appeal for denial of jury trial, 84 F.2d 265 (App. D.C., 1936); then affirmed on other grounds and remanded for new trial. The Court was divided on the Constitutional question. 
safe and secure within the limits of the law, and the rulers, too, kept within their due bounds, and not be tempted by the power they have in their hands to employ it to purposes, and by such measures as they would not have known, and own not willingly. ${ }^{168}$

Similar views were expressed by Montesquieu in $1748 .{ }^{169}$ And in 1772 the famous lexicographer, Dr. Samuel Johnson, stated:

The advantage which humanity derives from law is this: that the law gives every man a rule of action, and prescribes a mode of conduct which shall entitle him to the support and protection of society. That the law may be a rule of action, it is necessary that it be known; it is necessary that it be permanent and stable. The law is the measure of civil right; but if the measure be changeable, the extent of the thing measured never can be settled. ... It may be said, in the language of the schools, Lex non recipit majus et minus, - we may have a law, or we may have no law, but we cannot have half a law. We must either have a rule of action, or be permitted to act by discretion and by chance..$^{170}$

The tradition respecting certainty in the law was one of the roots from which this nation grew. Alexander Hamilton spoke with the voice of this tradition when he categorized "an arbitrary discretion in the courts" as a thing to be carefully avoided in a free government. ${ }^{171}$ Indeed, most of the delegates to the Philadelphia Convention were familiar with the writings of Locke and Montesquieu. ${ }^{172}$ Thus the political tradition respecting legal certainty was well represented at the Convention, and it became embodied in the famous checks and balances of the federal plan. ${ }^{173}$ The tradition is in all respects consistent with Blackstone's caveat that the undermining of the jury begun with trifling inroads may end with total abolition. ${ }^{174}$ And its policy of clarity and stability is precisely opposed to the vagueness and mutability of the Frankfurter-Corcoran proposal.

It might possibly be thought that the certainty requirement of our political tradition would be satisfied by the drawing of an arbitrary line defining at the present time the extent of the Constitutional criminal jury guarantees. ${ }^{175}$ But a

${ }^{168}$ Locke, Second Essay on Civil Government, para. 137 (1690); cf. id., paras. 21, 136, 202.

${ }^{169}$ Montesquieu, The Spirit of the Laws, bk. VI, c. 3, para. 2; bk. XI, c. 6, para. 17, bk. XXVI, c. 2. para. 5 (1748).

${ }^{170}$ Boswell, Life of Samuel Johnson, Ll. D. (1791). Attorney Boswell used Jobnson's argument in Wilson v. Smith \& Armour, June 19, 1772: Faculty Decisions, Lord Hailes' Decisions 482. McNair, Dr. Johnson and the Law 50 (Cambridge, 1948).

171 Hamilton, The Federalist No. 78, second last paragraph: "To avoid an arbitrary discretion in the courts, it is indispensable that they should be bound down by strict rules and precedents, which serve to define and point out their duty in every particular case that comes before them...."

172 Nevins and Commager, Pocket History of the United States 129 (1943).

${ }_{173}$ Beard and Beard, op. cit. supra note 37, at 131; Coleman, op. cit. supra note 37, at c. XVIII; The Federalist Nos. 47, 48, 51, 57. Cf. Montesquieu, The Spirit of Laws, bk. XI, c. 6.

${ }^{174} 4$ Blackstone Comm. 343-44.

175 Contra: Frankfurter and Corcoran 981. 
major difficulty of such line-drawing arises from the collateral problems presented thereby. What about the immunity against self-incrimination, the right to counsel, and other safeguards promised in the Bill of Rights? ${ }^{\text {?76 }}$ Presumably any cases excluded from the jury assurances would also be excludible from the accompanying Constitutional safeguards relating to "criminal" proceedings. A grave deficiency of the Frankfurter-Corcoran position is that it raises such problems but gives no hint of any solution to them. If we accept their thesis that "criminal" excludes "petty offenses" from its meaning, it is unclear what Constitutional protections if any would be available to the accused in such cases.

Fortunately these problems were anticipated and obviated by the drafters of the Constitution. They took the shortest and simplest route through this thicket of difficulties and made the Constitutional provisions equally applicable to all criminal cases. To obliterate and ignore the all-encompassing line drawn by the drafters and in its place to substitute the unclear, uncertain and inconstant distinction of Frankfurter and Corcoran is to mock the efforts of the Constitutional framers. There is little enough clarity and certainty in the law, which fact reflects small credit on the legal profession. Let us then treasure that little, and work toward its increase rather than its demolition.

The policy considerations just discussed uniformly favor employment of the criminal jury in its full expressed and intended scope under the Constitution. They plainly combine with the Constitutional language to require abolition of summary criminal jurisdiction. Since no logical inconsistency exists between such abolition, the prior summary practice, and the silent records of the drafters' debates, the sound conclusion is that federal criminal prosecutions without jury are improper where jury trial is demanded by the defendant. Frankfurter and Corcoran failed to reach this conclusion because they accorded too much weight to history and too little to individual liberty and to the actual words of the Constitution, which on their face are most comprehensive. With all the evidence and arguments now set forth, the reader can readily perceive that the proper procedure for "petty offense" prosecutions is clearly and aptly stated in the comprehensive rule: "The trial of all crimes... shall be by jury...."

\section{The Position of the Supreme Court}

A single decision of the United States Supreme Court upholds the view that congressional power to dispense with the criminal jury subsists under the Constitution. In that case, District of Columbia v. Clawans, ${ }^{177}$ the defendant received a sixty-day jail sentence on summary conviction of selling second-hand property without a license. Applicable statues prohibited such selling, provided a maximum ninety-day jail term for violators, and prescribed summary trial for infractions. In reaching its decision upholding the Constitutionality of the statu-

176 U.S. Const. Amends. V and VI; cf. Amend. VIII.

177300 U.S. 617 (1937). 
tory procedure the Court relied on the Frankfurter-Corcoran article already dealt with above, and on three earlier Supreme Court cases interpreting the Constitutional jury provisions.

None of these cases by any means justifies the Clawans holding. In fact, two of them are contrary to Clawans in sustaining the right to jury trial under the Constitution. Thus Callan v. Wilson ${ }^{178}$ held unconstitutional a summary conviction of conspiracy, where the defendant was sentenced to a month's imprisonment in default of payment of a $\$ 25$ fine. Likewise, in District of Columbia v. Colt $^{179}$ a defendant summarily sentenced to thirty days confinement for the misdemeanor of seriously reckless driving was held entitled to trial by jury.

Any judicial speculation on collateral matters contained in the opinions in these two cases is an inadequate ground for the Clawans decision. The great criticism of such dictum as precedent arises from the probable superficiality of the analysis it subsumes. ${ }^{180}$ This is a quite sufficient and entirely proper reason for confining the Callan and Colts cases to the issues actually presented for resolution in them. So confined, they lend no support to the proposition that a federal judge, without the intervention of a jury, may exercise an arbitrary discretion over the liberty of persons appearing in his court to answer criminal charges.

Schick v. United States, ${ }^{181}$ the third case invoked to justify the Clawans decision, similarly fails to support it when restricted to its facts. ${ }^{182}$ Schick was charged with violating a provision of the Oleomargarine Act which subjected the offender to a $\$ 50$ penalty. He waived jury trial. His subsequent conviction by the court was held not to be inconsistent with the Sixth Amendment. In the Clawans prosecution a jury had been demanded, but this distinction, though alone probably dispositive of all precedent value in the earlier case, need not be relied upon here. For it is entirely sufficient to differentiate the two cases completely that in Schick no risk of imprisonment was involved; the liberty of the accused was not at stake.

But it is only where personal liberty is involved that the jury guarantees of Article III and Amendment VI come into play. Alexander Hamilton said that the friends of the plan of the Federal Convention, who as to this matter constituted the more conservative group, regarded the trial by jury "as a valuable safeguard to liberty."183 Hamilton's further elucidation of the topic in The

178127 U.S. 540 (1888).

179282 U.S. 63 (1930).

${ }^{180}$ Alexander v. Baltimore Ins. Co., 4 Cranch. (U.S.) 370,379 (1808); Lawson v. United States, 176 F.2d 49, 51 (App. D.C., 1949); Grigsby v. Reib, 105 Tex. 597, 602, 153 S.W. 1124, 1126 (1913). Cf. Williams v. United States, 289 U.S. 553, 570 (1933); Ex parte Bakelite Corp., 279 U.S. 438,455 (1929).

181195 U.S. 65 (1904).

182 Restricted, it may be added, in accord with the suggestion of Frankfurter and Corcoran 979.

${ }^{183}$ The Federalist No. 83. 
Federalist ${ }^{184}$ clearly shows that the jury assurance of Article III was designed, in accordance with the attitude of the time, to secure personal liberty, and that the protection of private property was left to Congressional statutory regulation. Thus he writes:

I cannot readily discern the inseparable connection between the existence of liberty and the trial by jury in civil cases. Arbitrary impeachments, arbitrary methods of prosecuting pretended offenses, and arbitrary punishments upon arbitrary convictions, have ever appeared to me to be the great engines of judicial despotism; and these have all relation to criminal proceedings. The trial by jury in criminal cases, aided by the habeas-corpus act, seems therefore to be alone concerned in the question. And both of these are provided for, in the most ample manner, in the plan of the convention. ${ }^{185}$

The language of the Amendments of 1791 is easily read consistently with Hamilton's conception that the preservation of liberty was exclusively the function of the criminal jury, and that the protection of property was primarily the task of the civil jury. For although Amendment VII preserved jury trial in all suits "at common law," which could mean criminal as well as civil proceedings, ${ }^{186}$ the right was restricted to cases where the value in controversy exceeded twenty dollars. The monetary limitation evokes the idea of property interests. Moreover, since certain proceedings criminal in form affected property rights by enforcing fines, penalties and forfeitures, extension of the Seventh Amendment's guarantee beyond private civil actions into this area could well have been intended. In harmony with this interpretation, the application of Amendment VI, assuring the safeguard of a jury against arbitrary imposition of the only remaining criminal sanctions of imprisonment or capital punishment, would be limited to cases involving life or liberty, consistently with Hamilton's analysis.

To justify this reading of the Sixth and Seventh Amendments in accord with Hamilton's assignment to the criminal jury of the preservation of liberty and to the civil jury of the protection of property, we need only resort to the 18th century rules of documentary interpretation. Those rules provided that the general words of a document were to be given force when, even though ostensibly limited by a particular enumeration, good reasons for such enumeration exist. ${ }^{187}$ In the Amendments the general words with which we are concerned are "suits at common law." 188 The particular enumeration purporting to limit them is "all criminal prosecutions."189 The question involved is not whether the

184 Ibid.

185 The Federalist No. 83. Hamilton's understanding of the criminal jury assurance of Article III as a measure designed to secure liberty conforms to 18 th century rules of documentary interpretation, in reading the general intent expressed in the Preamble into the subsequent specific provision.

${ }^{186}$ Accord: Crosskey, op. cit. supra note 53 , at 767-84.

${ }^{187}$ Id., at c. XIII; see especially 369.

188 U.S. Const. Amend. VII. ${ }^{189}$ Id., at Amend. VI. 
enumeration wholly desitalizes the general provision, since that would make one Amendment out of two, but to what extent the one diminishes the other. And the answer to this question is quickly found in the occasion of the particular enumeration.

The character of the Seventh Amendment, like the New Jersey type of jury guarantee, ${ }^{190}$ was preservative only. Its language was arguably broad enough to apply to cases covered by the absolute guarantee in Article III. Lest it be deemed to diminish the earlier assurance ${ }^{191}$ and thus detract from the liberty thereby secured, the absolute guarantee was re-expressed contemporaneously with the preservative provision. In other words, the jury provision of the Sixth Amendment was made as an extra precaution to ensure that the corresponding provision in Article III would escape diminution by the Seventh Amendment.

Consequently, the assurance of a criminal jury is co-extensive in Article III and Amendment VI. ${ }^{192}$ But since Article III was concerned solely with liberty and not property, ${ }^{193}$ only the cases involving death or imprisonment are taken out of the scope of the Seventh Amendment by the Sixth. And therefore the general words of the Seventh Amendment are effective as to all other cases, including proceedings criminal in form but only involving property rights; i.e., recoveries of fines, penalties and forfeitures.

That there is no novelty in this analysis is attested by the fact that the Federal Rules of Criminal Procedure explicitly provide for the same result. The Rules apply to "all criminal proceedings"194 except forfeitures of property and the collection of fines and penalties. ${ }^{195}$ Accordingly, the provision in Rule 23(a) for jury trial must apply only to cases wherein conviction may result in death or imprisonment, the sole additional criminal sanctions now in use. And Rule 23(a) "is a formulation of the constitutional guaranty of trial by jury."196

Clearly if the Schick case had arisen after the effective date ${ }^{197}$ of the Criminal Rules, it would be excepted from Rule 23(a) as a penalty collection suit. Just as clearly the Clawans case would be covered by the Rule, as one of the criminal proceedings not excepted. ${ }^{198}$ And as the Rule reflects the criminal jury assurances of the Constitution in accordance with Hamilton's conception thereof, it is evident that the two cases are distinct. For Schick was a property case governed by the Seventh Amendment, which explicitly preserved the pre-Constitutional rufe as to the right to a jury. Thus denial in that case of a jury trial, even

190 See text following note 46 supra.

${ }^{191}$ By retroactively destroying its absoluteness on the theory of replacement $a b$ initio and making it merely preservative of pre-existing law.

192 See note 111 supra. 194 Fed. Rules Crim. Proc. 1.

${ }^{193}$ See note 185 supra. ${ }^{195}$ Id., Rule 54(b) (5).

${ }^{196}$ Id., Rule 23(a), Notes of Advisory Committee on Rules.

197 March 21, 1946.

${ }^{198}$ The exception of "petty offenses" in Rule 54(b)(4) is incompetent to defeat the hypothesis proposed in the text, since its genesis is in the Clawans case. 
aside from waiver, was obviously consistent with the Sixth Amendment, because the Sixth Amendment applies only to a class of cases of which Schick was not a member. Contrariwise, Clawans was a liberty case within the scope of the Sixth Amendment, and was thereby excluded from the operation of the Seventh. Therefore that case was properly controlled, not by the preservative standard of the Seventh Amendment, but by the absolute guaranties of the Sixth and of Article III.

The consequence of this vital distinction is that reliance on Schick for the result of Clawans is misplaced. Realizing this, we can see plainly that the Clawans case is a departure from all reason, policy and precedent. The decision incorrectly assumed that pre-Constitutional history was inconsistent with a broad reading of the nation's jury assurances as absolute in all criminal cases; it took no account of the requirement of objective interpretation of the comprehensive language of the Constitution; it subsumed an area of "petty offenses" so vague as to contradict the great tradition of legal certainty which aroused the admiration of our Founding Fathers and inspired their federal plan; it respected as precedent what is at best undeliberated dictum; and it deprived a defendant entitled to a jury trial of her Constitutional safeguard. For all these reasons, the case must be regarded as creating extremely bad law. Because it is such cases which most merit the review essential to their overruling, it is much to be hoped that the Supreme Court will take an early opportunity to correct its position conformably to the lessons of history and the dictates of a better informed insight, and thereby improve the pitiful plight of the peerless petty offender against the laws of the United States. 